\title{
Pemanfaatan Computer Assisted Instruction Model Tutorial Untuk Meningkatkan Kemampuan Komunikasi Matematis Dan Kemandirian Belajar Siswa Dalam Pelajaran Matematika
}

\author{
Yopi Nugraha ${ }^{1}$, Dewanti Nurmayanti ${ }^{2}$ \\ ${ }^{1}$ Institut Pendidikan Indonesia Fakultas Ilmu Terapan Dan Science \\ Jl. Pahlawan No.32 Sukagalih Tarogong Garut \\ ${ }^{2}$ SMPN 2 Garut \\ Jl. Ahmad Yani No.40-8, Pakuwon, Garut Kota \\ yopi@institutpendidikan.ac.id ${ }^{1}$, dewantinurmayanti0112@gmail.com²
}

\begin{abstract}
:
The aims of this research is to determine the improvement of mathematical communication skills and student learning independence with the utilization of CAI Tutorial model. This research method is quasi experiment with population are students seventh grades in SMP Negeri 2 Garut, the sample are students in class VII-I as an experiment class and student in class VII-G as a control class. The instruments in this study in the form of written test. By using test one side and 5\% significant level, it can be concluded that the mathematical communication ability of students who get the learning with CAI utilization Tutorial model is significantly better than students who get conventional learning. And the result of student independence analysis to learning with utilization of CAI model Tutorial as a whole is positive or accept.
\end{abstract}

Key word : Computer Assisted Instruction ,CAI, model tutorial, communication skills, learning independence

Abstrak :

Penelitian ini bertujuan untuk mengetahui peningkatan kemampuan komunikasi matematis dan kemandirian belajar siswa dengan pemanfaatan CAI model Tutorial. Metode penelitian ini adalah kuasi eksperimen dengan populasi siswa kelas tujuh di SMP Negeri 2 Garut, sampelnya yaitu siswa kelas VII-I sebagai kelas eksperimen dan siswa kelas VIIG sebagai kelas kontrol. Instrumen dalam penelitian ini berupa tes tertulis. Dengan menggunakan uji satu pihak dan taraf signifikan 5\% diperoleh kesimpulan bahwa kemampuan komunikasi matematis siswa yang mendapatkan pembelajaran dengan pemanfaatan CAI model Tutorial lebih baik secara signifikan daripada siswa yang mendapatkan pembelajaran konvensional. Dan hasil analisis kemandirian belajar siswa terhadap pembelajaran dengan pemanfaatan CAI model Tutorial secara keseluruhan bersifat positif atau menerima.

Kata kunci : Computer Assisted Instruction,CAI, model Tutorial, kemampuan komunikasi, kemandirian belajar

\section{PENDAHULUAN}

Pendidikan Nasional bertujuan membentuk manusia yang beriman dan bertaqwa kepada Tuhan Yang Maha Esa, beretika (beradab dan berwawasan budaya bangsa Indonesia), memiliki nalar (maju, cakap, cerdas, kreatif, inovatif dan bertanggung jawab), berkemampuan komunikasi sosial (tertib dan sadar hukum, kooperatif dan komunikatif, demokratis), dan beradab sehat sehingga menjadi manusia mandiri (Mulyasa, 2004:21).

Melihat pentingnya pendidikan untuk masa depan bangsa, maka sekolah harus berupaya untuk meningkatkan mutu pendidikan khususnya mutu pendidikan matematika yang merupakan landasan dan kerangka pembangunan ilmu pengetahuan dan teknologi. Tugas dan peran guru bukan lagi sebagai pemberi informasi (transfer of knowladge), tetapi sebagai pendorong siswa belajar (stimulation of learning) agar dapat mengkonstruksi sendiri pengetahuan melalui berbagai aktifitas termasuk aspek berkomunikasi.

Aplikasi teknologi pendidikan sangat relevan bagi pengelolaan pendidikan pada umumnya dan kegiatan belajar mengajar pada khususnya. Salah satu media yang digunakan dalam pembelajaran, dan diyakini dapat lebih memacu kemampuan komunikasi serta kemandirian siswa dalam berlajar adalah multimedia interaktif CAI model Tutorial. CAI (Computer Assissted Instruction) adalah suatu sistem penyampaian materi pelajaran yang berbasis miskroprosesor yang pelajarannya dirancang dan diprogram ke dalam sistem tersebut. Dalam mode ini, komputer bisa menampilkan pembelajaran, menggunakan berbagai jenis media (teks, gambar, suara, video), menyediakan aktivitas dan suasana Stephen (1990 :120) bahwa program CAI yang baik haruslah meliputi empat aktivitas : a) informasi (materi pelajaran) harus diberikan atau keterampilan (skill) diberikan model; b) siswa harus diarahkan; c) siswa diberi latihan-latihan; d) pencapaian belajar siswa harus dinilai. 
Penggunaan media terlebih lagi media interaktif CAI model Tutorial menjadikan proses pembelajaran lebih efektif dan efisien, serta menarik sehingga banyak disenangi siswa. Menurut Hamalik (dalam Arsyad, 2011:15) siswa merasa lebih mudah memahami konsep melalui animasi, gambar-gambar, variasi warna, dan huruf yang ditampilkan dalam program. Perpaduan berbagai media tersebut mampu merangsang sel motorik siswa sehingga dapat meningkatkan hasil belajar siswa.

Menurut Asikin (dalam Darkasyi, 2014:1) komunikasi matematis dapat diartikan sebagai suatu peristiwa saling hubungan/dialog yang terjadi dalam suatu lingkungan kelas, dimana terjadi pengalihan pesan. Pesan yang dialihkan berisi tentang materi matematika yang di pelajari di kelas, komunikasi di lingkungan kelas adalah guru dan siswa. Sedangkan cara pengalihan pesan dapat secara tertulis maupun lisan yang disampaikan guru kepada peserta didik untuk saling komunikasi, sehingga komunikasi dapat berjalan dengan lancar dan sebaliknya. Jika komunikasi antara siswa dengan guru tidak berjalan dengan baik maka akan rendahnya kemampuan komunikasi matematis.

Fakta lain dilapangan menunjukkan bahwa kemampuan komunikasi matematis khususnya siswa SMP di Indonesia masih tergolong rendah. Berdasakan hasil observasi di sekolah, dalam kegiatan diskusi ada beberapa siswa yang kesulitan dalam menyampaikan hasil pemikirannya, siswa kurang memahami apa yang disampaikan siswa lain, siswa hanya menyelesaikan soal sejenis dengan soal yang sudah diselesaikan oleh guru, hal ini menunjukkan bahwa kemampuan komunikasi matematis beberapa siswa SMP masih kurang.

Berdasarkan pengamatan sementara di kelas VII SMPN 2 Garut ditemukan permasalahan, (1) masih kurangnya pemanfaatan CAI terlihat hampir $89 \%$ guru belum memahami penggunaan CAI. (2) Dan masih kurangnya kemampuan komunikasi matematis siswa, terlihat dari belum bisa membaca simbol-simbol matematika sehingga hasil belajar siswa pada mata pelajaran matematika belum mencapai target KKM yang telah di tetapkan. KKM yang telah ditetapkan adalah 72,00 sedangkan ratarata hasil belajar siswa adalah 6,87. (3) Serta yang terakhir, masih kurang kemandirian belajar siswa, yaitu siswa masih ketergantungan kepada guru sehingga enggan belajar jika tidak disuruh oleh guru, terlihat pada sikap mereka dalam pembelajaran masih banyak siswa yang mendapat nilai kurang dari 75, padahal standar nilai sikap yang diharapkan adalah 85 .

Berdasarkan uraian diatas maka penulis tertarik untuk melakukan penelitian mengenai peningkatan kemampuan komunikasi matematis dan kemandirian belajar siswa dengan penggunaan CAI model Tutorial.

\section{KAJIAN PUSTAKA}

CAI yaitu penggunaan komputer secara langsung dengan siswa untuk menyampaikan isi pelajaran, memberikan latihan dan mengetes kemajuan belajar siswa. CAI juga bermacam-macam bentuknya bergantung kecakapan pendesain dan pengembang pembelajarannya, bisa berbentuk permainan (games), mengajarkan konsep-konsep abstrak yang kemudian dikonkritkan dalam bentuk visual dan audio yang dianimasikan. Jadi CAI adalah penggunaan komputer sebagai alat bantu dalam dunia pendidikan dan pengajaran. CAI membantu siswa memahami suatu materi dan dapat mengulang materi tersebut berulang kali sampai ia menguasai materi itu." (Nurita, 2007).

Secara definisi tutorial adalah pembelajaran khusus dengan instruktur yang terkualifikasi dan penggunaan mikro komputer untuk tutorial secara khusus telah mencangkup tutorial dengan metode alternatif diantaranya bacaan, demonstrasi, penentuan bacaan atau pengalaman yang membutuhkan respon secara oral dan tulisan serta adanya ujian. Daramawan (2011: 139). Sedangkan menurut Nandi (2006 : 6) model tutorial merupakan program pembelajaran interaktif yang digunakan dalam PBM dengan menggunakan perangkat lunak atau software berupa program komputer berisi materi pelajaran. Komputer sebagai tutor berorientasi pada upaya dalam membangun prilaku siswa melalui penggunaan komputer. Secara sederhana pola-pola pengoperasiannya adalah sebagai berikut: 1) komputer menyajikan materi, 2) siswa memberi respon, 3) respon siswa di evaluasi oleh komputer, dengan orientasi pada siswa dalam menempuh prestasi berikutnya dan 4) menjalankan atau mengulangi tahap selanjutnya. Dapat disimpulkan bahwa CAI model Tutorial adalah suatu multimedia yang mengandung unsur paduan pembelajaran interaktif yang dilengkapi dengan alat pengontrol yang dapat dioperasikan oleh siswa, selanjutnya sistem akan memberikan feedback sesuai dengan pengoperasian siswa. 
Perancangan sebuah CAI model Tutorial haruslah sistematis sehingga tidak membingungkan pemakai program dalam proses pembelajaran.

Komunikasi adalah proses berbagi makna melalui prilaku verbal dan non verbal. Segala perilaku dapat disebut komunikasi jika melibatkan dua orang atau lebih (Mulyana, 2008). Indikator komunikasi matematis menurut NCTM (1989) antara lain : a) Kemampuan mengekspresikan ide-ide matematis melalui lisan, tulisan, dan mendemonstrasikannya serta menggambarkannya secara visual. b) Kemampuan memahami, menginterpretasikan, dan mengevaluasi ide - ide matematis baik secara lisan, tulisan, maupun dalam bentuk visual lainnya. c) Kemampuan dalam menggunakan istilah-istilah, notasi-notasi matematika dan struktur-strukturnya untuk menyajikan ide-ide, menggambarkan hubungan-hubungan dengan model - model situasi.

Menurut Umar dan Sulo (2005: 50) "kemandirian belajar diartikan sebagai aktivitas belajar yang berlangsungnya lebih didorong oleh kemauan sendiri, pilihan sendiri, dan disertai rasa tanggung jawab dari diri pembelajar". Sedangkan menurut Abu Ahmadi (2004: 31), "kemandirian belajar adalah sebagai belajar mandiri, tidak menggantungkan diri pada orang lain". Ciri-ciri kemandirian belajar pada setiap siswa akan nampak jika siswa telah menunjukkan perubahan dalam belajar. Siswa belajar untuk bertanggung jawab terhadap tugas yang dibebankan padanya secara mandiri dan tidak bergantung pada orang lain.

\section{METODE PENELITIAN}

Metode yang digunakan dalam penelitian ini adalah metode kuasi eksperimen atau eksperimen semu. Penelitian ini menggunakan pendekatan eksperimen dengan penelitian dalam bentuk randomized pretest-posttest Control Group Design, yaitu desain kelompok kontrol dan kelompok eksperimen pretest dan posttest. Dimana paling tidak melibatkan dua kelompok belajar yang mendapat perlakuan yang berbeda satu sama lainnya (Arikunto, 1997 :80).

Tabel 1. Desain penelitian ini digambarkan sebagai berikut :

\begin{tabular}{clll}
\hline $\mathrm{E}:$ & $\mathrm{O}$ & $\mathrm{X}$ & $\mathrm{O}$ \\
$\mathrm{K}:$ & $\mathrm{O}$ & & $\mathrm{O}$ \\
\hline
\end{tabular}

\section{Keterangan :}

E : Eksperimen

$\mathrm{K}$ : Kontrol

$\mathrm{O}$ : Observasi (test)

$\mathrm{X} \quad$ : Perlakuan dengan menggunakan CAI model tutorial

Mengingat penelitian ini dilaksanakan disuatu sekolah dengan kelas-kelas yang sudah terbentuk sebelumnya dan subjek-subjek yang tidak mungkin untuk dilakukan pengacakan, maka metode eksperimen yang digunakan berjenis eksperimental semu atau kuasi eksperimen. Adapun populasi yang diambil dalam penelitian ini adalah siswa kelas VII SMP Negeri 2 Garut tahun pelajaran 2016/2017 yang terdiri dari sebelas kelas. Kemudian dari populasi tersebut diambil sampel sebanyak dua kelas yaitu kelas VII-I sebagai kelas eksperimen dan kelas VIIG sebagai kelas kontrol.

\section{HASIL DAN PEMBAHASAN}


Data kuantitatif pada penelitian ini diperoleh hasil tes awal (pretest) dan tes akhir (posttest) pada kelas eksperimen dan kelas kontrol dengan skor ideal 36.

Tabel 2. Statistik Deskriptif Data Hasil Pretest

\begin{tabular}{cccc}
\hline \multirow{2}{*}{ No } & Ukuran & \multicolumn{2}{c}{ Pretest } \\
& Statistik & Eksperimen & Kontrol \\
\hline 1 & Nilai Terendah & 1 & 0 \\
2 & Nilai Tertinggi & 6 & 6 \\
3 & Rata - rata & 3,48 & 2,77 \\
& Simp. Baku & $9,67 \%$ & $7,69 \%$ \\
4 & 1,76 & 1,50 \\
5 & Skor Ideal & 36 & 36 \\
\hline
\end{tabular}

Dari tabel 2. terlihat bahwa nilai rata-rata pretest kelas eksperimen sebesar 3,48 dengan persentase 9,67\% dari skor ideal 36. Sedangkan untuk kelas kontrol sebesar 2,77 dengan persentase $7,69 \%$ dari skor ideal 36. Jika dilihat dari persentase nilai pretest kedua kelas tersebut maka terlihat perbedaan nilai pretest sebesar 1,98\% dengan persentase nilai rata-rata kelas eksperimen lebih tinggi terhadap kelas kontrol.

Tabel 3. Statistik Deskriptif Data Hasil Postest

\begin{tabular}{cccc}
\hline \multirow{2}{*}{ No } & Ukuran & \multicolumn{2}{c}{ Postest } \\
& Statistik & Eksperimen & Kontrol \\
\hline 1 & Nilai Terendah & 11 & 4 \\
2 & Nilai Tertinggi & 22 & 21 \\
3 & Rata - rata & 15,93 & 12,00 \\
& Simp. Baku & $44,25 \%$ & $33,33 \%$ \\
4 & Skor Ideal & 36 & 4,17 \\
5 & & 36 \\
\hline
\end{tabular}

Berdasarkan tabel 3. terlihat bahwa nilai rata-rata postest kelas eksperimen sebesar 15,93 dengan persentase $44.25 \%$ dari skor ideal 36. Sedangkan untuk kelas kontrol sebesar 12,00 dengan persentase 33,33\% dari skor ideal. Jika dilihat dari persentase nilai postest kedua kelas tersebut maka terlihat perbedaan nilai posttest sebesar 10,92\% dengan persentase nilai rata-rata kelas eksperimen lebih tinggi terhadap kelas kontrol.

Berdasarkan hasil perhitungan pretest kemampuan komunikasi matematis, diketahui bahwa kemampuan awal kelompok eksperimen dan kelompok kontrol berbeda secara signifikan. Untuk mengetahui bahwa peningkatan kemampuan komunikasi matematis siswa kelompok eksperimen lebih baik dari kelompok kontrol, maka selanjutnya dilakukan pengujian gain ternormalisasi.

Berikut ini disajikan analisis statistik deskritif data skor gain ternormalisasi kelas eksperimen dan kelas kontrol.

Tabel 4. Deskripsi Gain

\begin{tabular}{cccc}
\hline \multirow{2}{*}{ No } & Ukuran & \multicolumn{2}{c}{ Gain Ternormalisasi } \\
& Statistik & Eksperimen & Kontrol \\
\hline 1 & Nilai Terendah & 0,30 & 0,04 \\
2 & Nilai Tertinggi & 0,76 & 0,73 \\
3 & Rata - rata & 0,53 & 0,38 \\
4 & Simp. Baku & 0,14 & 0,16 \\
5 & Skor Ideal & 27 & 30
\end{tabular}

Dari tabel 4. terlihat nilai rata-rata dan simpangan baku nilai gain setiap kelompok, untuk kelompok eksperimen diperoleh nilai rata-rata 0,53 dengan simpangan baku 0,14 , sedangkan untuk kelompok kontrol diperoleh nilai rata-rata 0,38 dengan simpangan baku 0,16 . Jika dilihat dari nilai gain kedua kelas tersebut maka terlihat perbedaan nilai dengan nilai rata-rata kelas eksperimen lebih tinggi terhadap kelas kontrol. Selanjutnya akan diuji peningkatan rata-rata data skor gain siswa kelas eksperimen dan kelas kontrol

Tabel 5. Hasil Peningkatan rata-rata data skor Gain

Sgabungan Db thitung tabel




\section{$0,15 \quad 55 \quad 3,85 \quad 1,6725$}

Pada tabel 5. terlihat bahwa nilai thitung $=3,85$ dengan taraf signifikan 5\% diperoleh nilai $t_{\text {tabel }}=1,6725$. Karena $t_{\text {hitung }}>t_{\text {tabel }}$, maka hipotesis nol ditolak. Dengan demikian peningkatan rata-rata data skor gain siswa kelas eksperimen dan kelas kontrol adalah berbeda. Sehingga dapat disimpulkan pembelajaran dengan pemanfaatan CAI model Tutorial lebih baik daripada siswa yang mengikuti pembelajaran konvensional dalam meningkatkan kemampuan komunikasi matematis siswa. Secara keseluruhan terjadi peningkatan kemampuan komunikasi matematis dengan pemanfaatan CAI model Tutorial dengan nilai rata-rata skor gain ternormalisasi sebesar 0,53 dengan kualitas peningkatan sedang.

Skala Kemandirian Belajar Siswa dilihat dari data angket. Pemberian angket bertujuan untuk mengetahui kemandirian belajar terhadap pembelajaran matematika, dan pemanfaatan CAI model Tutorial, serta terhadap mengkomunikasikan masalah matematika.

Tabel 6. Interpretasi Skala Sikap

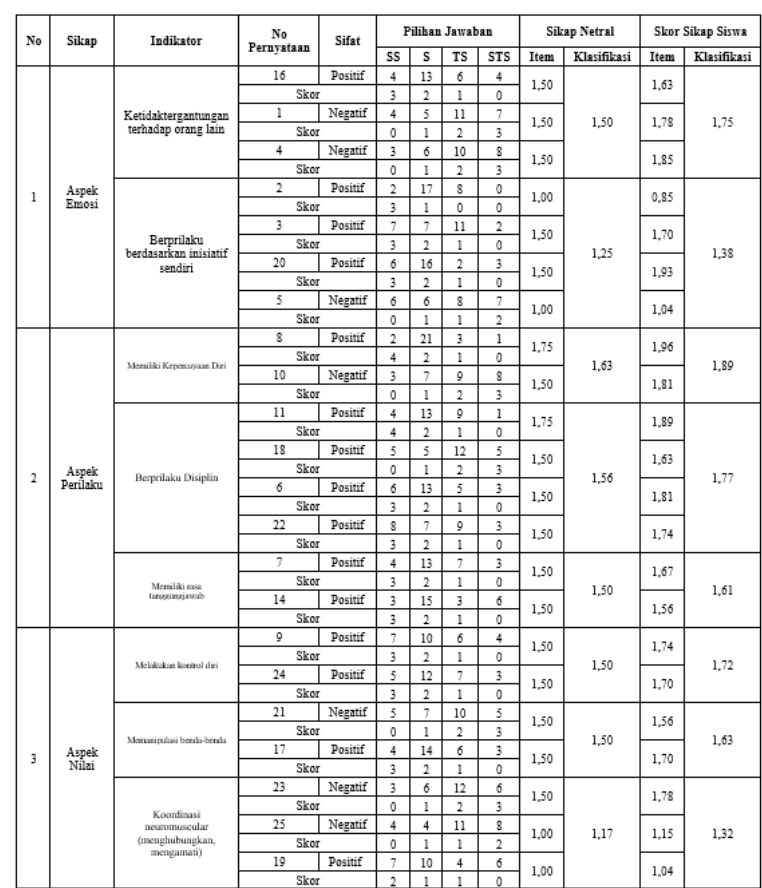

Sikap siswa untuk aspek emosi terhadap pemanfaatan CAI model Tutorial ini cukup baik, ditunjukkan oleh perbandingan rata-rata skor siswa 1,57 terhadap skor netral 1,38. Artinya siswa cukup termotivasi dalam belajar matematika, siswa berminat untuk belajar matematika secara mandiri.

Sikap siswa untuk aspek ini cukup baik dengan perbandingan rata-rata skor siswa 1,76 terhadap skor netral 1,56. Artinya siswa cukup respon pada pembelajaran yang dilakukan yaitu dengan pemanfaatan CAI model Tutorial.

Sikap siswa untuk aspek ini cukup baik dengan perbandingan rata-rata skor siswa 1,56 terhadap skor netral 1,39. Artinya siswa memiliki kemauan sendiri dan mempunyai kepercayaan diri yang tinggi dalam menyelesaikan tugasnya tanpa ketergantungan kepada orang lain.

Pemanfaatan CAI model Tutorial mendapat respon yang positif dari siswa. Sikap terhadap pembelajaran matematika mendapat respon positif, dan sikap terhadap pembelajaran dengan pemanfaatan CAI model Tutorial mendapat respon positif. Kondisi ini memberikan kontribusi yang baik bagi kemandirian belajar siswa dalam belajar matematika terutama dalam kemampuan komunikasi matematis siswa. 
p-ISSN : 2655-7304

e-ISSN : 2655-8963

\section{KESIMPULAN DAN SARAN}

Berdasarkan hasil analisis data dan pembahasan, dapat dikemukakan kesimpulan sebagai berikut, bahwa pemanfaatan CAI model Tutorial lebih baik daripada siswa yang mendapatkan metode pembelajaran konvensional dalam meningkatkan kemampuan komunikasi matematis dan kemandirian belajar siswa. Terjadinya peningkatan kemampuan komunikasi matematis dengan pemanfaatan CAI model Tutorial dengan kategori peningkatan sedang.

\section{DAFTAR PUSTAKA}

Ahmadi, Abu. (2004). Teknik Belajar yang Efektif. Jakarta: PT. Rineka Cipta

Arikunto, Suharsimi. (1997). Prosedur Penelitian Suatu Pendekatan Praktek. Jakarta: Rineka Cipta.

Arsyad, A. (2011). Media Pembelajaran. Jakarta: Raja Grafindo Persada.

Darkasyi, M, dkk. (2014). Peningkatan Komunikasi Matematis dan Motivasi Siswa dengan Pembelajaran Pendekatan Quantum Learning pada Siswa SMP Negeri 5

Lhokseumawe. Jurnal Didaktik Matematika. Magister Pendidikan Matematika Program Pascasarjana Universitas Syiah Kuala, Banda Aceh. Vol.1 No.1

Darmawan, D. (2011). Teknologi Pembelajaran. Bandung: PT Remaja Rosdakarya.

E. Mulyasa. (2004). Kurikulum Berbasis Kompetensi: Konsep, Karakteristik, dan Implementasi. Bandung : Rosdakarya.

Nandi. (2006). Penggunaan Multimedia Interaktif Dalam Pembelajaran Geografi Dipersekolaha. Jurnal "GEA” Jurusan Pendidikan Geografi Vol.6, No.1. FPIPS : UPI Bandung. Tidak diterbitkan.

Mulyana, Deddy. (2008). Metodologi Penelitian Komunikasi. Bandung : Remaja Posda Karya.

National Council of Teachers of Mathematics (NCTM). (1989). Curriculum and Evaluation Standards for School Mathematics. Reston VA : The National Council of Teachers of Mathematics inc.

Nurita. P. (2007). Komputer sebagai Alat Bantu Pembelajaran. Nurita Putranti, htm.

WordPress. Com

Robbins, Stephen. 1990. Prilaku Organisasi, Jakarta: Prehalindo.

Umar dan La Sulo. (2005). Pengantar Pendidikan. Jakarta : PT Rineka Cipta. 